\title{
Aktivitas Meronce Dengan Media Tangkai Ubi Kayu Terhadap Kemampuan Berhitung Permulaan Anak
}

\author{
Nursila Abdullah', Bujuna Alhadad ${ }^{2}$, Andi Agustan Arifin ${ }^{3}$ \\ Universitas Khairun Ternate \\ Fakultas Keguruan dan Ilmu Pendidikan \\ Jl. Bandarah Sultan Baabullah Kota Ternate Utara, Kotak Pos 53 Ternate 977328 \\ Telepon: (0921) 3110905-Faksimili 0921-3110901
}

Email: silanursila77@gmail.com¹, bujunaalhadad@gmail.com², agus_anzone@yahoo.co.id ${ }^{3}$

\begin{abstract}
Abstrak: Kegiatan meronce dengan media tangkai ubi kayu pada kemampuan berhitung, awal anak merupakan penelitian yang bertujuan untuk meningkatkan kemampuan anak melalui kerja sama dengan orang tua anak dan untuk meningkatkan pelaksanaan perencanaan program dengan lebih tepat lebih baik membuat sesuatu yang baru atau memodifikasi yang sudah ada. Teknik pengumpulan datanya adalah dokumentasi dan untuk analisis datanya menggunakan metode analisis isi. Hasil analisis bertujuan bahwa kegiatan meronce dengan media tangkai ubi kayu bermanfaat untuk meningkatkan perkembangan otak terkait kemampuan berhitung yaitu pembelajaran konsep bilangan.
\end{abstract}

Kata Kunci: Kegiatan Meronce, Tangkai Ubi Kayu, Keterampilan Berhitung.

\begin{abstract}
Abstrak: Meronce activity with cassava stalk media on children's early numeracy ability is a research that aims to improve children's abilities through collaboration with parents of students, and to improve the implementation of program planning more appropriately better making something new or modify existing. The research method used a literature study approach. The data collection techniques is documentation, and for data analysis using the content analysis method. The results of this analysis indicate that the meronce activity with cassava stick media is useful for improving brain development related to numeracy ability, namely learning of number concept.
\end{abstract}

Key Words: Meronce Activity, Cassava Stick, Numeracy Skill

\section{A. Pendahuluan}

Pendidikan adalah usaha sadar dan terencana untuk mewujudkan suasana belajar dan peroses pembelajaran agar peserta didik secara aktif mengembangkan potensi dirinya untuk memiliki kekuatn spiritual keagamaan, pengendalian diri,kepribadian, kecerdasan, ahlak mulia, serta keterampilan yang diperlukan dirinya ,masyarakat, bangsa dan Negara. (Undang-undagn Nasional no 20 tahun 2003 Bab I Pasal I). Berdasarkan penjelasan diatas pendidikan itu sangat penting untuk mengembangankan semua apa yang dimiliki oleh semua manusia yang hidup didunia ini, oleh karna pentingnya pendidikan jadi semua elemen baik pemerintah maupun masyarakan mengembangkan pendidikan sejak masih dalam kandungan yang di tangani oleh kesehatan dan kependudkan denagn memperhatikan ibu hamil dan dislenggarakan di masing Posyandu.

Pendidikan Anak Usia Dini (PAUD) adalah suatu upaya pembinaan yang ditunjukan kepada anak sejak lahir sampai dengan usia 6 tahun, yang dilakukan melalui pemberian rangsangan pendidikan untuk membantu pertumbuhan dan perkembangan jasmani dan rohani. Agar anak memiliki kesiapan dalam memasuki pendidikan lebih lanjut, (Undang-undang nomor 20 tahun 2003 pasal 1 ayat 14).

Pendidikan di Taman kanak-kanak (TK) di laksanakan dengan prinsip belajar melalui bermain sesuai dngan perkembangan dan pertumbuhannya, oleh sebab itu di 
harapkan seorang pendidik yang kretif dan inovatif agar anak bias merasa senang, tenang, aman dan nyaman, selama dalam peroses belajar mengajar. Dalam standar kopetensi kurikulum TK tercantum bahwa tujuan pendidikan adalah membantu mengembangkan berbagai potensi anak baik pisik dan pisihis yang meliputi nilai-nilai agama sosial, emosi, konitip, bahasa, pisikomotorik, kemandirian dan seni untuk persiapan memasuki pendidikan dasar.

Sesuai dengan peraturan pemerintah nomor 137 tahun 2014 tentang standar nasional pendidikan anak usia dini bab 2 pasal 2ayat 1 standar PAUD terdiri atas standar tingkat pencapaiaan perkembangan anak, setandar isi, setandar proses, standar penilaian, standar pendidik dan tenaga kependidikan, standar sarana dan prasarana, standar pengelolaan, standar pembiayaan, standar ini merupakan satu kesatuan yg tidak terpisahkan dalam pengelolaan dan penyelenggaraan pendidikan anak usia dini (PAUD)dan menjadi acuan dalam mengembangkan implementas dan epaluasi kurikulum paud. Pasal 4 standar PAUD bertujuan mnjamin mutu pendidikan anak usia dini dalam rangka member landasan untuk melakukan stimulan pendidikan dalam membantu pertumbuhan dan perkembangan jasmani dan rohani sesuai tingkat pencapain perkembangan anak, mengotimalkan perkembangan anak secara holistik dan integrative dan mempersiapkan pertumbuhan sikap pengetahuan dan keterampilan anak. untuk mencapain tujuan tersebut di atas di lakukan evaluasi dan di sempurnakan secara terencana, terarah dan berkelanjutan sesuai dengan pertumbuhan lokal, nasional dan global.

Masa kanak-kanak adalah masa pertumbuhan dan perkembangan yang sangat menentukan masa selanjutnya. Usia dini adalah masa yang penuh dengan kejadiankejadian penting dan unik yang meletakkan dasar bagi kehidupan seseorang di masa dewasa. Usia taman kanak- kanak merupakan salah satu rentang umur pada anak usia dini, yaitu usia 4 sampai 6 tahun. Masa ini disebut masa keemasan. Kerena peluang perkembangan anak yang sangat berharga. Dengan demikian, anak usia dini disebut sebagai golden age atau usia emas yang dikarenakan bahwa aspek perkembangan anak usia dini akan tumbuh dan berkembang secara optimal melalui stimulasi yang diberikan pada usia tersebut dan mengalami peningkatan perkembangan sesuai dengan peningkatan usia anak. Pertumbuhan dan kemampuan anak menyangkut segala aspek yaitu aspek bahasa, aspek fisik, aspek sosial emosional, aspek kognitif, aspek nilai moral agama dan seni. Hal ini harus berjalan dengan seimbang dan dengan baik. Salah satu aspek yang harus berkembang dengan baik adalah aspek kognitif anak usia dini yang merupakan aspek yang sangat penting untuk anak dalam melakukan aktivitas dan mendukung pertumbuhannya. Sementara itu, sesuai dengan Peraturan Menteri Pendidikan Nasional No 58 tahun 2009 dalam mengontrol pembelajaran anak usia, penerapan pembelajaran pendidikan di Taman Kanak-Kanak (TK) tidak diperkenankan mengajarkan materi calistung secara langsung, sehingga perlu media untuk mengenalkan pembelajaran tersebut. Penggunaan alat peraga yang menarik perhatian dan dapat meningkatkan minat dan motivasi anak untuk belajar. Menurut Vygotsky dalam Tedjasaputra (2001: 9) bahwa bermain mempunyai peran langsung terhadap perkembangan kognitif seorang anak karena anak belum mampu berfikir abstrak tanpa obyek nyata yang ada disekitarnya. Oleh sebab itu pelaksanaan pembelajaran di TK tidak lepas dari permainan. Dengan bermain akan menimbulkan perasaan senang dan menarik bagi anak. Rasa senang yang diperoleh melalui bermain sangat memungkinkan anak belajar tanpa paksaan atau tekanan.media meronce adalah segala sesuatu yang dapat dipergunakan untuk menyalurkan pesan dan dapat merangsang pikiran yang mencerminkan wujud penghargaan terhadap keindahan benda-benda yang ada di alam, digunakan bisa seperti benda ronce dengan bahan bekas, dengan manik-manik dan dengan biji-bijian. Kemampuan berhitung merupakan salah satu kegiatan belajar yang mampu mengembangkan kemampuan dasar 
matematika anak seperti kemampuan, melihat, membedakan, meramalkan, memisahkan dan mengenal konsep angka, selain itu juga mampu meningkatkan kemampuan anak dalam memecahkan masalah. Namun seperti yang kita lihat saat ini, pada sebagian besar pemahaman anak belum mampu menyebutkan dan mengurutkan lambang bilangan dengan tepat. Dimana sebagian besar masih terbalik mengurutkan angka sehingga belum memenuhi standar pencapaian perkembangan anak. Hal ini terbukti pada saat guru memberikan tugas pada anak untuk mengurutkan angka 1 dan seterusnya, ternyata anak didik belum bisa mengurutkan angka dengan benar. Sehingga Hal ini menunjukkan bahwa kemampuan memahami konsep bilangan pada anak didik dalam mengurutkan dalam mengurutkan lambang bilangan belum tepat. Aktivitas meronce dengan media tangkai ubi kayu terhadap kemampuan berhitung permulaan anak penting untuk dilaksanakan sebagai salah satunya salah satu kegiatan yang dapat memanfaatkan lingkungan sekitar serta dapat mengenalkan benda yang ada di alam sekitar dalam pembelajaran di Taman Kanak-kanak.

\section{B. Metode Penelitian}

Dalam penelitian ini menggunakan kajian pustaka. Kajian pustaka dalam suatu penelitian ilmiah adalah salah satu bagian penting dari keseluruhan langkahlangkah metode penelitian. Metodologi yang digunakan dalam penelitian ini dengan pendekatan studi literatur. Metode penelitian dengan pendekatan studi literatur merupakan penelitian yang serangkaian kegiatannya dengan metode pengumpulan data pustaka, buku-buku, serta dan tulisan yang terkait dengan judul penelitian ini dari perpustakaan kamus online (contoh wikipedia) dan dari internet yang dapat memperkuat naskah yang akan dipublikasikan (Mustika, 2004). Sementara itu Irawan berpendapat bahwa metode dokumentasi merupakan teknik yang ditunjukan kepada subjek penelitian, dokumen yang diambil dalam berbagai macam sumber seperti: catatan pribadi, surat pribadi, buku-buku, catatan kasus, rekaman video/suara, foto dan lain sebagainya (Sukandarrumidi, 2012).

\section{Pembahasan}

Setiap anak dilahirkan dengan kecerdasan dan potensi yang berbeda-beda. Perbedaan individu ini yang menyebabkan ada perbedaan kemampuan pada setiap anak. Masa kanak-kanak merupakan masa yang efektif untuk mengembangkan potensi yang dimiliki anak, dimana mereka tumbuh, berkembang, berkreasi dan menjadikan pengalaman yang sangat berharga ketika anak mulai menjalani kehidupan. Pada usia tersebut anak mengalami masa keemasan (golden age), karena pada masa ini anak mengalami pertumbuhan dan perkembangan yang sangat pesat. Mencapai tingkat perkembangan yang optimal keterlibatan antara orang tua maupun guru sangat penting. Orang tua atau guru dapat memberikan rangsangan dan melatih kecerdasan serta kemampuan yang dimiliki anak.

Potensi-potensi yang dimiliki setiap anak yang dapat dikembangkan meliputi perkembangan nilai agama dan moral, psikomotorik, kognitif, bahasa serta sosial emosional. Kemampuan kognitif merupakan salah satu dari kemampuan-kemampuan yang harus dicapai dalam pembelajaran anak usia dini. Seperti yang membagi empat tahap perkembangan kognitif anak usia dini dan salah satunya pada tahap pra operasional Piaget.

Sesuai dengan Peraturan Menteri Pendidikan Nasional (Permendiknas) No 58 tahun 2009 dalam mengontrol pembelajaran anak usia 5-6 tahun, penerapan pembelajaran pendidikan di Taman Kanak-kanak (TK) tidak diperkenankan mengajarkan materi calistung secara langsung, sehingga perlu media untuk mengenalkan pembelajaran tersebut. Penggunaan alat peraga yang menarik perhatian dan dapat meningkatkan minat dan motivasi anak untuk belajar. 
Menurut Hurlock dalam Astuti (2007:14) menyatakan bahwa kehidupan lima tahun pertama merupakan peletak dasar bagi perkembangan selanjutnya. Anak yang mengalami masa bahagia berarti terpenuhinya segala kebutuhan fisik maupun psikis di awal perkembangannya diramalkan akan dapat melaksanakan tugas-tugas perkembangan selanjutnya. Maka dapat disimpulkan bahwa mempelajari bagaimana belajar yang terbentuk pada masa pendidikan di TK akan tumbuh menjadi kebiasaan di tingkat pendidikan selanjutnya.

Menurut Vygotsky dalam Tedjasaputra (2001:9) bahwa bermain mempunyai peran langsung terhadap perkembangan kognitif seorang anak karena anak belum mampu berfikir abstrak tanpa obyek nyata yang ada disekitarnya. Oleh sebab itu pelaksanaan pembelajaran di TK tidak lepas dari permainan. Dengan bermain akanmenimbulkan perasaan senang dan menarik bagi anak. Rasa senang yang diperoleh melalui bermain sangat memungkinkan anak belajar tanpa paksaan atau tekanan. Dengan kendor atau rileksnya syaraf-syaraf otak dan organ tubuh sehingga selain aspek motoriknya, kecerdasan anak akan dapat berkembang secara optimal.

Pengertian Bermain menurut Konvensi Hak-Hak Anak (1990) pasal 31 dalam Tedjasaputra (2001:xvi) disebutkan "hak anak untuk beristirahat dan bersantai, bermain dan turut serta dalam kegiatan-kegiatan rekreasi yang sesuai dengan usia anak yang bersangkutan dan untuk turut serta secara bebas dalam kehidupan budaya dan seni". Jadi bermain adalah dunia anak dan menjadi hak setiap anak. Melalui bermain anak dapat mengembangkan aspek fisik motorik, kecerdasan dan sosial emosional yang akan saling menunjang dan harus diberikan kesempatan untuk berkembang secara optimal.

Rose \& Nicholl dalam Putra \& Ninin (2012), menegaskan dalam suasana yang menyenangkan belajar dapat dirasakan sebagai petualangan seumur hidup, perjalanan eksplorasi tanpa akhir untuk menciptakan makna. Belajar yang menyenangkan menimbulkan rasa senang dan menarik perhatian anak, secara tidak langsung anak memperoleh satu atau beberapa pembelajaran sekaligus tanpa anak sadari. Kegiatan peningkatkan kemampuan kognitif dengan cara yang menyenangkan dapat diberikan kepada anak usia dini diantaranya yaitu melalui kegiatan meronce.

Meronce adalah menyusun atau menata benda dengan menggunakan seutas tali. Dengan teknik ikatan akan memanfaatkan bentuk ikatan menjadi lebih lama dibandingkan tanpa ikatan. Prinsip-prinsip berhitung melalu imeronce (Depdiknas, 2007:2). Berhitung permulaan diberikan secara bertahap, diawali dengan menghitung manik-manik yang akan dironce. Permainan dimulai dari yang mudah ke permainan yang sukar. Beberapa pendapat ahli menjelaskan pengertian meronce adalah suatu seni merangkai objek benda menjadi sesuatu yang menarik dengan bantuan tali atau benang, banyak produk yang bisa dibuat dengan seni meronce diantaranya kalung, tasbih, gelang, hiasan gordyn kamar dan lain sebagainya, seni meronce biasanya digunakan untuk kepentingan komersil, hasil produk dari meronce bisa dijual dan mendapatkan keuntungan. Namun seni meronce juga perlu diajarkan ke anak-anak karena manfaatnya besar untuk anak. Manfaat utama dari meronce yaitu membantu merangsang perkembangan saraf motorik halus anak, bermain dengan cara memasukkan benang ke lubang benda satu persatu hingga membentuk panjang, memasukkan benang kedalam lubang ini bisa merangsang kemampuan saraf motorik halus anak, melatih kesabaran anak serta melatih fokus dan konsentrasi anak. Sangat banyak manfaatnya. Selain yang disebutkan diatas, bermain meronce juga bisa melatih kemampuan imajinasi anak, karena meronce adalah seni, untuk anak yang memiliki bakat seni yang baik pasti akan menyusun ronce menjadi bentuk yang bagus, misalnya anak akan menyusun kombinasi bentuk dan warna ronce yang menarik sesuai dengan imajinasinya. 
Media meronce adalah segala sesuatu yang dapat dipergunakan untuk menyalurkan pesan dan dapat merangsang pikiran yang mencerminkan wujud penghargaan terhadap keindahan benda-benda yang ada di alam, digunakan bisa seperti benda ronce dengan bahan bekas, dengan manik-manik dan dengan biji-bijian.

Pamadhi (2011) menyatakan bahwa dari konsep umumnya meronce mempunyai tujuan permainan yakni meronce dapat berfungsi untuk alat bermain anak, benda-benda yang akan dirangkai tidak ditujukan untuk kebutuhan tertentu melainkan untuk latihan memperoleh kepuasan rasa dan memahami keindahan. Kegiatan meronce mampu melatih kemampuan kognitif anak melalui pemahaman terhadap warna, pola dan mengurutkan benda berdasarkan ukuran yang dirangkai.Kegiatan yang dapat digunakan dalam meningkatkan kemampuan anak usia dini dalam aspek perkembangan kognitif yaitu melalui kegiatan meronce dengan berbantuan bahan alam. Berdasarkan jenis dan bentuknya bahan merangkai dapat dikelompokkan menjadi dua bagian penting: (a) bahan alam, dan (b) bahan artifisal atau bahan buatan. Jenis bahan dasar untuk meronce salah satunya adalah bahan alam, yaitu bahan yang langsung diambil dari alam, seperti buah, batang, cabang, serta bebatuan.

Angraini (2013) menyatakan bahwa kegiatan meronce adalah salah satu kegiatan yang diberikan kepada anak pra sekolah. Permainan meronce adalah salah satu aktivitas yang bermanfaat untuk perkembangan otak anak. Dengan bermain meronce anak tidak hanya memperoleh kesenangan, tetapi juga bermanfaat untuk meningkatkan perkembangan otaknya. Dengan meronce anak-anak bisa membuat bentuk apapun dengan simpul tali atau dengan kreatifitasnya masing-masing. Montolalu dalam Sunarto (2016) berpendapat kegiatan tersebut yaitu memasukkan manik-manikke dalam benang, Meronce mempunyai susunan yang variatif, mulai dari menggunakan komponen-komponen yang sama bentuknya akan tetapi berbeda ukuran, sampai dengan komponen yang tidak sama bentuknya tetapi disusun berdasarkan bentuk yang sama. Dengan demikian manfaat meronce yaitu dapat menstimulus beberapa aspek salah satunya adalah sebagai pengasah kemampuan kognitif anak, meronce bukanlah sekedar aktivitas permainan yang mana di dalamnya, ada banyak pelajaran yang bisa kita gali untuk didapat oleh sang anak. Anak belajar warna, anak belajar bentuk, anak belajar pola, anak juga belajar konsep jumlah (berapa banyak).

Meronce merupakan suatu kegiatan untuk dapat merangkai manik-manik menjadi kesatuan berdasarkan kriteria tertentu, seperti berdasarkan warna, bentuk manik-manik, atau jumlahnya. Meronce juga bisa merangsang motorik halus, saat meronce aneka bentuk anak dapat melatih untuk berpikir, memahami dan melihat bagaimana sebuah tali dapat masuk kelubang yang kecil. Media bahan alam yaitu bahan bahan yang ada di lingkungan sekitar yang paling mudah dicari, ditemui dan paling dekat dengan lingkungan sekitar dalam kehidupan kita sehari-hari. ciri media bahan alam yaitu mudah dibuat dan bahannya mudah didapat. Bahan dan alat yang digunakan dalam meronce mempunyai peranan penting dalam pembuatan suatu karya, bahan-bahan yang dapat digunakan meronce ada bahan-bahan alam atau alami dan non alam. Salah satu upaya dalam pengembangan kogitif adalah melalui pengembangan matematika. Istilah yang dikenal dalam pengembangan kognitif diantaranya: pengembangan daya pikir, atau ada juga yang menyebutkan sebagai pengembangan kecerdasan logika matematika. Kegiatan pengembangan matematika untuk anak usia dini dirancang agar anak mampu mengembangkan kemampuan berpikir, mendorong anak untuk mengembangkan berbagai potensi intelektual yang dimilikinya serta dapat dijadikan sebagai sarana untuk menumbuhkan berbagai sikap dan perilaku positif dalam rangka meletakkan dasar-dasar kepribadian sedini 
mungkin seperti sikap kritis, ulet, mandiri, ilmiah, rasional, dan lain sebagainya. Matematika bagi anak usia dini merupakan salah satu cara bagi anak untuk menguasai berbagai pengetahuan dan keterampilan matematika yang memungkinkan mereka untuk hidup dan bekerja pada saat mendatang yang menekankan pada kemampuan memecahkan masalah (Sriningsih, 2008 dalam Nurhanifah, 2015).

Dengan demikian, kegiatan merangkai dan meronce memerlukan beberapa aspek atau pengetahuan dasar untuk membuatnya, diantaranya adalah aspek tujuan dan fungsi, prinsip penyusunan dan penataan, aspek bahan, aspek teknik, aspek penyelesaian.

1. Aspek Tujuan dan Fungsi Pembuatan

Karya kerajinan seperti merangkai dan meronce mempunyai tujuan yang berbeda dengan melukis dan menggambar. Aspek ini yang menentukan bentuk akhir, misalnya: ketika akan membuat roncean gelang manik-manik, seorang anak yang kemudian membuatnya tidak diikatkan satu diantaranya sehingga mirip untaian bebas, maka tidak dapat dikatakan sebagai roncean.

Dilihat dari konsep umumnya merangkai dan meronce mempunyai tujuan:

a. Permainan

Merangkai maupun meronce dapat berfungsi untuk alat bermain anak, benda-benda yang akan dirangkai tidak di tujukan untuk kebutuhan tertentu melainkan untuk melatih memperoleh kepuasan rasa dan memahami keindahan. Seorang guru dapat meminta anak didiknya untuk membawa bekal makanan secukupnya, anak diminta untuk menata makanannya didalam piring plastik yang sudah disiapkan oleh guru. Maka dengan meminta menata, sekaligus anak terlibat dalam bermain.

b. Kreasi dengan komposisi

Kemungkinan benda atau komponen lain dapat diminta oleh guru kepada anak untuk menyusun ala kadarnya. Benda-benda tersebut dikumpulkan dari lingkungan sekitar, seperti: papan bekas, kotak sabun atau yang lain yang dibayanngkan dapat menjadi bangunan megah. Anak sengaja hanya bermain imajinasi saja, sehingga tujuan bermain ini untuk melatih imajinasi atau bayangan anak tentang konstruksi suatu bangunan.

Secara garis besar manfaat penataan ini adalah;

1) Melatih imajinasi melalui bentuk dan konstruksi bentuk dan bahan.

2) Melatih ketelitian melalui kecermatan merangkai serta menyusun bendabenda tersebut.

3) Melatih keajegan atau irama melalui urutan, tingkatan, serta kedudukan masing-masing benda terhadap benda yang lain,

4) Melatih rasa kebersamaan, jika merangkai secara bersama-sama,

5) Ekspresi atau mengutarakan pendapat melalui pengandaian bentuk untuk menyatakan keinginannya terhadap benda yang diminta.

6) Kegiatan bermain bagi anak sebenarnya merupakan latihan untuk mengenal benda serta sesuatu yang ada dilingkungan sekitarnya melalui peniruan.

c. Gubahan atau inovasi

Merangkai dan meronce dapat ditujukan untuk melatih kreativitas, yaitu dengan cara mengubah fungsi lama menjadi fungsi baru. Seni merangkai ini lebih cendrung dikatakan sebagai seni bentuk dengan teknik merangkai dan meronce.

2. Aspek Keindahan

Aspek keindahan dari merangkai dan meronce terletak pada cara menyusun benda-benda sebagai komponen rangkaian dapat menarik perhatian. 
Penataan ini menggunakan prinsip penyusunan seperti pada membentuk dan melukis, sebagai berikut.

a. Kesatuan, yaitu prinsip menyusun yang bertujuan agar susunan tersebut menarik

b. Keseimbangan dengan memperhatikan masing-masing ukuran, bentuk serta pengikatnya, apakah berupa garis, warna pengikat serta yang lain.

c. Irama adalah penyusun yang memperhatikan ukuran benda, besar kecil yang tersusun seperti irama music dengan rumus:

1) a-b-a-b-a-b dst atau

2) a-b-b-b-a yang dapat disusun berirama adalah warna, misalnya dengan warna panas dan dingin atau gelap-terang.

Aspek keindahan dapat diajarkan secara langsung dengan berlatih, untuk itu guru senantiasa mampu memotivasi dengan beberapa anjuran. Pemberian contoh diperlukan untuk mengasah pengamatan serta rasa. Seorang guru ketika akan member contoh perlu mengklasifikasi:

a. apakah anak telah mempunyai konsep penataan

b. jika sudah, guru melanjutkan dengan beberapa pertanyaan tentang konsep tersebut

c. jika anak belum mempunyai konsep penciptaan,guru dapat memancingnya dengan pertanyaan, tentang gagasan apa yang akan di tuangkan dalam rangkaian tersebut.

3. Aspek Kerajinan dan Ketekunan

Aspek kerajinan meliputi kemampuan mengamati bentuk berdasarkan kegunaannya, berdasarkan tujuan penelitian dan penciptaan. Aspek kerajinan menuntut ketelitian yaitu usaha member pelatihan, menyusun, menata rangkaian yang sesuai dengan rancangan susunannya tidak mudah rusak. Ketelitian yang di maksud adalah cermat dalam memilih bahan dan memilih bentuk yang akan di susun secara konseptual, serta ketelitian dalam menyelesaikan tugasnya:

a. Tidak mudah rusak

b. Warna dan bentuknya sesuai

c. Sesuai dengan tujuan penciptaan, apakah untuk kebutuhan praktis, hiasan serta ekspresi.

Salah satu bagian dari matematika adalah berhitung. Berhitung merupakan dasar dari beberapa ilmu yang digunakan dalam kehidupan seharihari seperti penambahan, pengurangan, pembagian, ataupun perkalian. Untuk anak usia dini dapat menambah dan mengurangi serta membandingkan sudah sangat baik setelah anak memahami bilangan dan angka (Suyanto, 2005:73). Sesuai dengan Permendikbud No.137 tahun 2014 tentang standar nasional pendidikan anak usia dini, dalam standar tingkat pencapaian perkembangan anak kelompok usia 4-6 tahun, bahwa lingkup perkembangan kognitif khususnya bagian berpikir simbolik terdapat beberapa tingkat pencapaian perkembangan, diantaranya: "(1) membilang banyak benda 1-10; (2) mengenal konsep bilangan; (3) mengenal lambang bilangan; (4) menyebutkan lambang bilangan 1-10; (5) menggunakan lambang bilangan untuk berhitung; (6) mencocokkan bilangan dengan lambang bilangan."

Rusmayadi (2016) berpendapat bahwa kecerdasan logika matematika anak dapat diberikan dengan berbagai cara yaitu dengan memperkenalkan bentuk geometri, membandingkan benda yang ada di sekitar anak, mencocokkan benda, mengklasifikasi benda berdasarkan bentuk-warna-dan ukuran, mengenalkan pola, dan pengenalkan konsep penjumlahan dan pengurangan.

Hal ini didukung juga oleh beberapa penelitian yang dilakukan oleh Sukartini dkk (2019) dengan judul "Upaya meningkatkan kemampuan berhitung 
permulaan dengan permainan meronce" bahwa dengan melalui permainan meronce dapat meningkatkan kemampuan berhitung permulaan anak dimana hasil penelitian menunjukkan bahwa kemampuan berhitung permulaan 1-10 pada pratindakan sama dengan 40,57\%, siklus I sama dengan 60,26\%, siklus II sama dengan 79\%. Mardiyana (2014) dengan judul "Pengaruh kegiatan meronce terhadap kemampuan mengenal pola pada anak kelompok A di TK Wifa" hasil analisis data antara kelompok eksperimen dan kelompok kontrol dalam mengenal pola, diperoleh harga nilai U1 (26) dari kelompok eksperimen lebih kecil daripada kelompok kontrol yaitu U2 (169). Pada taraf signifkansi 0,05 dengan jumlah n1 = 13 dan $\mathrm{n} 2$ = 13 diperoleh $\mathrm{U}$ tabel 39 maka harga $\mathrm{U}$ hitung lebih kecil daripada $\mathrm{U}$ tabel $(26<39)$ sehingga Ho ditolak dan Ha diterima. Maka dapat disimpulkan bahwa kegiatan meronce berpengaruh secara signifikan terhadap kemampuan mengenal pola pada anak kelompok A Taman Kanak-kanak WIFA Bangkalan. Selain itu penelitian yang berjudul "Kemampuan mengenal konsep bilangan menggunakan media meronce pada anak usia dini di TK Pertiwi Disbun Pontianak" oleh D Ramadina (2019) juga menunjukkan kemampuan mengenal konsep bilangan menggunakan media meronce dapat dilihat dari keseharian anak dalam hal mengenal konsep bilangan dari indikator yang diamati yaitu menyebutkan lambang bilangan1-10, menggunakan lambang bilangan untuk menghitung, mencocokkan bilangan dengan lambang bilangan bahwa 10,52\% anak yang mangalami kesulitan dalam mengurutkan bilangan masih terbolak-balik di kelas B1 TK Pertiwi Disbun Pontianak Tenggara.

Kajian Penelitian yang Relevan Penelitian Tindakan Kelas ini, dilakukan oleh Nuryatmi (2010) dengan judul "Upaya Peningkatan Kemampuan Kognitif Anak Melalui Bermain Hitung Hasil Kebun" menyimpulkan bahwa kegiatan berhitung merupakan salah satu aspek kegiatan kognitif yaitu mampu untuk berfikir logis. Kegiatan berhitung akan lebih menarik, menyenangkan dan mengasyikkan bagi anak maka dilakukan dengan permainan bervariasi dari lingkungan anak bisa digunakan sebagai sumber bahan belajar atau alat untuk mengembangkan kemampuan berhitung anak yaitu bermain hitung hasil kebun.

Kegiatan meronce untuk meningkatkan kemampuan kognitif anak usia dini juga telah didukung oleh penelitian sebelumnya yang diketahui bahwa kegiatan meronce dapat meningkatkan kreativitas anak berdasarkan penelitian yang dilakukan oleh Widiastini, dkk. (2013), meningkatkan motorik halus anak,berdasarkan penelitian yang dilakukan oleh kemampuan kognitif anak mengenal bentuk geometri. Jadi dapat disimpulkan bahwa meronce salah satu cara untuk memberikan stimulasi kecerdasan logika matematika anak. Dari beberapa roncean anak dapat mengklasifikasi berdasarkan warna, bentuk, dan ukurannya. Saat memasukkan roncean anak dapat belajar menghitung menjumlah dan mengurangi roncean yang akan dibuat. Anak dapat membandingkan panjang roncean yang sudah dibuat dengan roncean miliktemannya.Saat anak meronce juga dapat mengenal pola (warna, ukuran, dan bentuk).

Berikut penjelasan yang dapat dilihat, tentang aktivitas meronce dengan media tangkai ubi kayu terhadap kemampuan berhitung permulaan anak dalam pelaksanaan pembelajaran anak usia dini di Taman Kanak-Kanak (TK) yaitu:

a. Bahan dan alat

Untuk lebih jelasnya bahan dan alat yang digunakan dalam penelitian ini adalah batang ubi kayu. Menurut Sumanto (2005: 159) Bahan dasar yang digunakan secara umum untuk meronce meliputi bahan alam dan bahan buatan. Bahan alam adalaah semua jenis bahan yang dapat diperoleh dari lingkungan alam sekitar secara langsung. Contoh dari bahan alam adalah bunga segar, buah-buahan, bunga kering, daun kering, ranting dan biji-bijian. 
Sedangkan bahan buatan adalah jenis bahan yang merupakan hasil produk atau buatan manusia, baik berbentuk bahan setengah jadi, bahan jadi atau bahan bekas. Contoh bahan buatan seperti monte, manik-manik, pita sintetis, kertas berwarna, sedotan minuman, plastik. Selain itu ada juga bahan pembantu untuk menambah kesan keindahan hasil rangkaian yang dibuat antar lain berupa lem, tali, benang, cat, pernis dan lainnya.

b. Tahap Meronce

Kegiatan meronce mempunyai beberapa tahap perkembangan. Anak dapat dikatakan siap diajari membaca jika sudah bisa meronce dengan menggunakan pola. Anak sudah bisa mulai mengklasifikasikan sesuatu pada tahapan ini. Di samping itu dalam pelajaran membaca anak harus bisa membedakan bentuk huruf, sama halnya dengan meronce anak-anak juga harus bisa membedakan bentuk bahan alam dan warna yang akan disusun.

c. Langkah-langkah Meronce

Dalam tahapan meronce sudah dijelaskan untuk langkah-langkah melaksanakannya sampai selesai. Dari tahapan tersebut dapat dijadikan pedoman untuk melaksanakan kegiatan meronce. Dalam hal ini meronce akan dilaksanakan dengan menggunakan bahan alam. Untuk langkah-langkah pembelajaran untuk kegiatan meronce di antaranya:

1) Meronce dengan berbagai media

a) Bahan (batang ubi kayu)

b) Langkah pembelajaran

- Siapkan potongan benang untuk dibagikan pada masing-masing anak.

- Siapkan batang ubi kayu sesuai dengan yang diinginkan.

- Kondisikan anak sebelum kegiatan meronce dimulai.

- Kenalkan pada anak bahan yang digunakan untuk meronce.

- Berikan contoh pada anak tentang kegiatan meronce.

- Ubi kayu dironce satu persatu sesuai dengan contoh guru

- Dalam meronce dapat dikombinasikan dengan bahan lainnya yang mendukung kegitan meronce.

- Jika sudah selesai ujung benang sementara diikat dengan ujung benang pada pangkal agar tidak lepas.

Penjelasannya sebagai berikut: langkah-langkah yang ditempuh dalam kegiatan meronce adalah sebagai berikut:

a) Tahap persiapan, yang meliputi:

- Guru membuat rencana kegiatan harian (RPPH) sebagai acuan dalam melaksanakan kegiatan meronce.

- Guru mempersiapkan kegiatan main melalui kegiatan meronce, menyiapkan alat dan bahan untuk kegiatan meronce

- Guru menyiapkan lembar observasi aktivitas anak dalam kegiatan meronce.

- Guru menyiapkan kamera untuk data visual dan dokumentasi.

b) Tahap Pelaksanaan, yang meliputi:

- Guru mengelola awal lingkungan main untuk kegiatan meronce

- Guru merencanakan intensitas dan identitas main

- Guru menyiapkan alat main meronce

- Guru menyeting tempat main meronce

- Guru memberi gagasan bagaimana menggunakan bahan-bahan. Guru mendiskusikan aturan main meronce

- Guru mengelola anak menjadi beberapa kelompok 
- Guru merancang dan menerapkan transisi main

- Guru memberikan anak waktu mengelola dan meneliti alat main

- Guru mempersilahkan anak untuk melakukan kegiatan dengan jelas

- Guru melakukan pencatatan aktivitas siswa termasuk kemampuan motorik halus

- Guru memberikan dukungan anak mengingat kembali pengalaman mainnya.

c) Tahap Penutup/ evaluasi meliputi:

- Guru menggunakan waktu untuk membereskan peralatan main

- Guru mengatur anak untuk persiapan selesai main

- Guru memperhatikan dokumentasi kemampuan motorik halus anak

- Guru menutup kegiatan dengan do"a.

Secara garis besar kegiatan meronce jelas dapat meningkatkan kemampuan berhitung permulaan. Keberhasilan peningkatannya dapat dilihat baik anak didik maupun gurunya yaitu:

a) Meningkatnya motivasi anak dalam mengikuti proses pembelajaran. Anak mengalami kesulitan dalam belajar berhitung permulaan. Anak merasa bosan dan jenuh sehingga anak sering malas apabila diajak belajar berhitung. Namun setelah bermain dengan media batang ubi kayu, anak lebih senang dan tertarik, anak tidak lagi mengalami kesulitan dalam berhitung permulaan apalagi dilakukan sambil bermain sehingga semua anak dapat ikut berpartisipasi aktif.

b) Meningkatnya kemampuan guru.

Kemampuan guru dalam pengelolaan kelas meningkat baik. Guru sudah menggunakan alat peraga yang menarik dan mudah didapat sebagai salah satu sarana penunjang kegiatan pembelajaran, dan dilaksanakannya prinsip pembelajaran di TK yaitu belajar seraya bermain dan bermain seraya belajar.

\section{Simpulan}

Meronce meimiliki hakikat yang sama dengan kata merangkai. Karena itu hakikat meronce yaitu menata, menumpuk, menyejajarkan, menyusun benda-benda atau pernik menggunakan teknik ikatan. Aktivitas meronce dengan media ubi kayu adalah salah satu aktivitas yang bermanfaat untuk perkembangan otak anak. Dengan bermain meronce anak tidak hanya memperoleh kesenangan, tetapi juga bermanfaat untuk meningkatkan perkembangan otaknya, anak juga belajar konsep jumlah (berapa banyak) dan dapat memanfatkan bahan alam yang ada di sekitar kita yakni batang ubi kayu. 


\section{DAFTAR PUSTAKA}

Anggraini Adityasari, 2013. Main Matematika Yuk. Jakarta: PT Gramedia Pustaka

Arikunto. S. 2001. Dasar-Dasar Evaluasi Pendidikan. Jakarta: Bumi Aksara

Akhmad Solihin. 2014. Fungsi dan Manfaat Bermain Balok (Online). Tersedia: http://paudanakbermainbelajar.blogspot.co.id/2014/10/fungsi-dan-manfaat-bermain-balokblock.html. Diakses tanggal 01 Juni 2016

Aqib, Zainal. 2010. Profesionalisme Guru dalam Pembelajaran. Surabaya: Insan Cendekia

Arsyad, Azhar. 2011. Media Pembelajaran. Jakarta: PT Raja Grafindo Persada

Corebima, AD, dkk. 2010. Penelitian Tindakan Kelas. Ternate: LepKhair

D. Ramadina. 2019. Kemampuan mengenal konsep bilangan menggunakan media meronce pada anak usia dini di TK Pertiwi Disbun Pontianak htpp://openjurnal.unmuhpnk.ac.id/JME/ artikel

Fajarwati Elli, 2009 Hubungan Antara Alat Permainan Balok dengan Kreativitas Anak TK

Freeman dan Munandar. 1997. Bermain dan Belajar. Jakarta: PT Grasindo

Hamalik, Oemar. 1994. Media Pendidikan. Bandung: Citra Adtya Bakti

Hani Nurhanifah, 2015 Upaya Meningkatkan Kemampuan Berhitung Anak Taman Kanak-Kanak Melalui Kegiatan Meronce Universitas Pendidikan Indonesia | Repository.Upi.Edu. Perpustakaan.Upi.Edu

Kemp, J.E. \& Dayton. D.K. 1985. Planning and Producing Instrutional Media (Fifth Edition)”.New York: Harper \& Row. Publishers

Mardiyana. 2014. Pengaruh kegiatan meronce terhadap kemampuan mengenal pola pada anak kelompok A di TK Wifa' Program Studi PG-PAUD, Fakultas Ilmu Pendidikan, Universitas Negeri Surabaya

Moeleong, L.J. Metodelogi Penelitian Kualitatif. Bandung: PT Remaja Rosdakarya

Nurfadilah.2014. Mengenal Huruf Hijaiyah dengan Permainan yang Menyenakan untuk Anak Taman Kanak-Kanak. (Online). http://tkalirsyadpwt.blogspot.co.id/2014/03/mengenal-hurufhijaiyah-dengan-berbagai.html. Diakses pada 01 Juni 2016

Rusmayadi Herman.2016.Sumber Belajar Materi PLPG 2016/ Mata Pelajaran Atau Keahlian Guru Kelas TK.

Sadiman, Arief S. 1993. Media Pendidikan. Jakarta: Raja Grafindo Persada

Sudjana, N. 2001. Penilaian Hasil Proses Belajar Mengajar. Bandung: PT. Remaja Rosdakarya

Sudarna. 2012. Pendidikan Anak Usia Dini Berkarakter". Jakarta: PT Elex Media Komputindo

Sunarto, 2016. Pengaruh Meronce Manik-Manik Terhadap Kemampuan Kognitif Anak Usia 7-8 Tahun, Volume 3, Nomor 2, Oktober 2016

Sukartini dkk. 2019. Upaya meningkatkan kemampuan berhitung permulaan dengan permainan meronce. Prosiding Seminar Nasional Pendidikan STKIP Kusuma Negara PAUD-038. Jurnal.stkipkusumanegara.ac.id 
Smaldino, Sharon E.; Deborah L. Lowther; dan James D. Russell. 2011. "Intructional Technology and Media For Learning (Teknologi Pembelajaran dan Media Untuk Belajar)" Diterjemahkan oleh Arif Rahman. Jakarta: Kencana Prenada Media Group

Susilana, Rudi. 2009. Sumber Belajar dalam Pendidikan. Dalam Ilmu dan Aplikasi Pendidikan, Bagian II : Ilmu Pendidikan Praktis. Bandung: PT. Imperial Bhakti Utama

Sukandarrumidi, 2012, Metodologi Penelitian (Petunjuk Praktis Untuk Penelitian Pemula). Yogyakarta: Gajah Mada University Press

Undang Undang RI Nomor 20 Tahun 2003 Tentang Sistim Pendidikan Nasional

Zed, Mestika, 2004. Metode Penelitian Kepustakaan. Jakarta: Yayasan Obor Indonesia 